\title{
The Japanese Economy in the Nineteen Nineties
}

\section{Yasukichi Yasuba}

A $\mathrm{s}$ the financial bubbles of the 1980 s were burst by tight monetary policy, the Japanese economy plunged into an ongoing recession that is only now beginning to abate. Growth rates of real GDP were close to zero except for 1990, 1991, 1995 and 1996. The average annual growth rate for the entire period of 1990 to 1997 was only 1.6 per cent, in contrast to 4.1 per cent in the 1980 s and 4.4 per cent in the 1970s. The unemployment rate, which had never exceeded 2.9 per cent since 1960, surpassed that figure in 1994 and rose to 4.3 per cent in 1998 .

The discount rate of the Bank of Japan was reduced from 6.0 per cent in 1991 to 3.25 per cent in 1992 , and then to 0.5 per cent in 1995 . The impact on private capital formation however was not strong except in 1996 when surging investment demand pulled the growth rate up to a respectable - but not really satisfactory - 3.2 per cent. For years other than 1990 and 1991, the operating ratio of capacity was much less than 100 per cent, so that the Bank of Japan was not in a position to depend on monetary policy to stimulate demand.

Clearly the economy was caught in a liquidity trap, and fiscal policy was called upon to provide the necessary effective demand for growth. Yet, despite the present author's repeated demands (Yasuba, 1993a-e, 1994a-c, 1995, 1996, 1999) and those of another Keynesian, Haruki Niwa (1993), fiscal stimulus sufficient to close the negative gap of the operating ratio has never been provided. There was strong resistance from the officials of the ultra-conservative Ministry of Finance - whom I once described as committing a 'crime against humanity' (Yasuba, 1994c) - who were too much concerned with year-to-year budget deficits. There was also strong criticism from neoclassical theorists like Makoto Yano $(1991,1998)$ who repeated and further developed the theory of the ineffectiveness of fiscal policy on economic growth of Barro (1974) and Lucas $(1975,1976)$. As a result only half-hearted fiscal stimulus was made and the negative gap of the operating ratio from the 100 per cent utilisation level has never been closed. Consequently, the 'pump priming' role of fiscal policy has not been achieved.

Even though many hypotheses have been advanced to explain the poor performance of the Japanese economy in the 1990s, this paper suggests that the slow growth of the economy and the rapid accumulation of public debt may be explained with the use of simple Keynesian theory.

Yasukichi Yasuba is Professor of Economics and Economic History at Osaka Gakuin University. 


\section{Fiscal Policy and Japanese Economic Growth in the 1990s}

To determine whether fiscal policy was effective in promoting growth a simple multiplier model (a truncated Keynesian model) was applied. Multipliers estimated by the Japan Research Institute of 1.56 for autonomous expenditure and 1.43 for permanent tax cuts in 1993 and 1994 were adopted. Smaller multipliers of 1.21 for autonomous expenditure, 0.7 for permanent tax cuts and 0.4 for transitory tax cuts, are used by the Institute for 1997 to 1999, presumably reflecting the greater uncertainty in the light of the higher unemployment rate. For the intermediate years (1995 to 1996) multipliers of $1.40,1.00$ and 0.70 were interpolated. For the period before 1993, a multiplier of 1.80 for autonomous expenditure was extrapolated. There were no significant tax cuts before 1994.

The results of this analysis are shown in the Appendix. The first column in the table shows the increase (in 1990 prices) in private autonomous expenditure comprising private fixed capital formation, private inventory accumulation, net export surplus and the expenditure of non-profit organisations. Column 2 shows this increase after application of the autonomous expenditure multiplier expressed as a percentage of GDP in the previous year. It indicates the estimated growth rate of GDP as a result of the increase in private autonomous expenditure.

Growth was positive in 1990 and 1991, reflecting continuing strong private demand and the assistance of fiscal policy. Growth would have been negative through 1992 to 1994 without fiscal policy, reflecting the negative private capital formation caused by the negative gap of the operating ratio from the fullutilisation level. Without fiscal influence it would have been only 0.06 per cent in 1995. The growth rate for 1996 would have been 3.34 per cent rather than the actual rate of 3.11 per cent if not for the negative impact of fiscal policy. Investment demand was surging because of the narrowing negative gap in the operating ratio of capacity. The growth rate in 1997 would have been slightly positive $(0.19$ per cent) rather than the actual rate of -0.41 per cent had it not been pulled down by strongly negative fiscal policy.

Column 3 shows the demand gap - the difference between the actual growth rate and the estimated contribution from the growth of private autonomous expenditure - namely the difference between column 8 and column 2 . This gap is to be filled by the effect of fiscal policy. It is positive in all years except 1996 and 1997, indicating the use of fiscal policy to stimulate demand to achieve the actual growth rate.

Fiscal policy is indicated by changes in public expenditure (mostly public capital formation) (column 4) and tax cuts (column 5). To arrive at the contribution of fiscal policy to GDP growth, each change in public expenditure was multiplied by an autonomous expenditure multiplier and expressed as a percentage of GDP in the previous year. The treatment of tax cuts is more complex.

First, a distinction was made between permanent tax cuts and special or transitory tax cuts. The former were assigned larger multipliers $(0.70$ to 1.42 depending on the period) than the latter ( 0.40 to 1.00$)$. Second, the timing of a 
tax cut was also taken into account. For example, only one-third of the impact of the 1994 tax cut ( $¥ 5.5$ trillion), implemented as a tax refund in the middle of December, was assigned to fiscal 1994 and the rest was assigned to the next fiscal year. In fiscal 1995, ¥3.5 trillion of the tax cut was made permanent. Considering this fact a multiplier premium of 0.3 points was assigned to the $¥ 3.5$ trillion portion of the tax cut in 1995. Similarly a 0.4 point multiplier was applied to the abolition ( $¥ 2.0$ trillion) of the special tax cut (a transitory cut) in 1997. For the increase in the consumption tax (a permanent one of $¥ 4.4$ trillion) and the increase in social security tax ( $¥ 0.6$ trillion) and in medical insurance cost ( $¥ 0.8$ trillion) a permanent tax cut multiplier of 0.7 was applied. The increase in the cost of medical insurance was made effective on September 1 and so only 7/12 of the multiplier effect was judged to be effective for the fiscal year. (A good summary of these taxation changes is OECD, 1998: Ch. 1.)

The effect of fiscal policy is shown in column 6 . It is clear that much of the shortfall of total demand caused by the decline in private autonomous expenditure between fiscal 1990 and fiscal 1994 was rectified by fiscal policy, even though the use of fiscal policy was too timid to achieve full employment of capital stock and labour. This is shown by the absence of a reduction in the unemployment rate over the entire period (Figure 1) and a negative gap in the operating ratio of capacity after 1991 (Figure 2). In 1995, the growth of private autonomous demand was minimal. However, the $¥ 5.5$ trillion transitory tax cut introduced towards the end of the previous fiscal year and the $¥ 2.74$ trillion increase in public expenditure helped the economy to achieve a 2.80 per cent growth, of which fiscal policy accounted for 1.93 percentage points.

In 1996, a substantial increase in private capital formation narrowed the negative gap in the operating ratio from the full-utilisation level (Figure 2) and, despite the negative contribution of fiscal policy $(-0.23$ points), resulted in a growth rate of 3.17 per cent. Yet growth was not vigorous enough to reduce the unemployment rate (Figure 1). Finally, in a misguided move towards re-building public finance, the Hashimoto Government cut public expenditure by $¥ 0.77$ trillion and raised the consumption tax rate from 3 per cent to 5 per cent, increasing revenue by $¥ 4.4$ trillion. The special transitory tax cut of $¥ 2.0$ trillion of the previous year was terminated at the same time. These fiscal measures generated a 1.24 percentage points decline in GDP growth leading to negative growth of -0.41 per cent for fiscal 1997 .

Overall, fiscal policy explains much of the difference between the actual growth and the effect on growth of private autonomous expenditure. Shortfalls and excesses of the effect of fiscal policy are small and on average represent only 26.7 per cent of the demand gap except for 1997 . The average error of 0.29 per cent is well within the confidence interval at 99 per cent level from the zero means and all the individual deviations are in the same interval. In every year, except 1996 and 1997, fiscal policy tended to stimulate growth. However, growth was not sufficiently strong to achieve full employment of capacity and labour except in 1990 and 1991. (See the shortfall of the operating ratio from the fullutilisation level after 1991 in Figure 2 and the increase in the unemployment rate for the same period in Figure 1.) 
Figure 1: Growth Rate of Real GDP and the Unemployment Rate, 1990 to 1998 , Fiscal Years

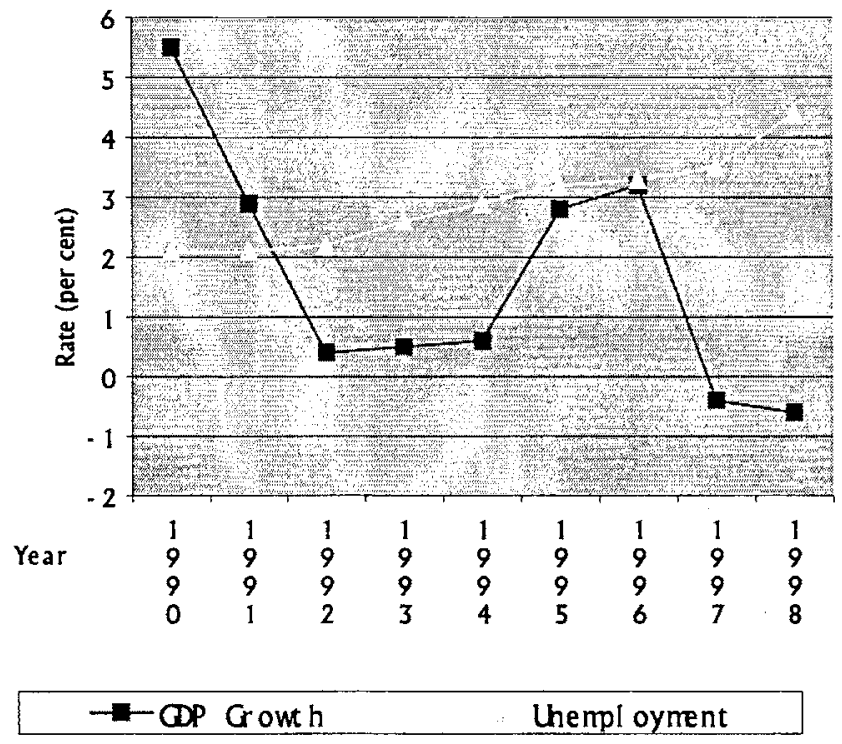

Source: Toyo Keizai Shinposha (1999:Statistical pages 2 and 12).

Figure 2: Operating Ratio of Capacity, Manufacturing, 1990 to 1998

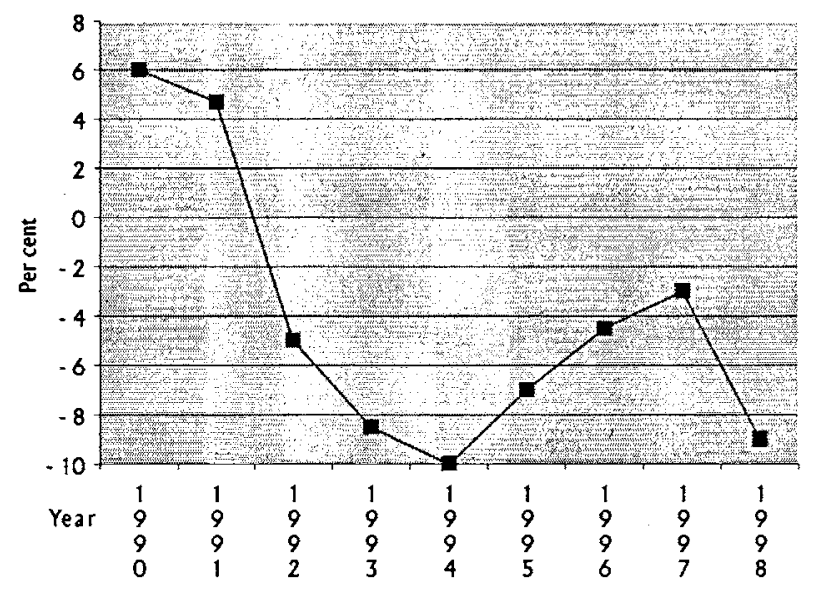

Source: OECD (1998:Ch. 1, Fig. 1). 
Since 1993 the author has consistently and publicly called for a substantial increase in fiscal stimulus to restore full employment of capital and labour, but the government has never adopted such a large-scale plan. One such proposal, in the spring of 1993, was for a permanent tax cut of $¥ 10$ trillion and public works expenditure of $¥ 4$ trillion (Yasuba, 1993c:22). Assuming these measures had been introduced towards the end of fiscal 1993 to be fully effective in 1994, the growth rate in that year would have been an estimated 4.51 per cent and the economy would have moved towards a fuller utilisation of capital and possibly of labour.

\section{Fiscal Policy and the Public Debt}

It has often been asserted that, as a result of Keynesian extravagance, the government is on the brink of national bankruptcy and that Japan is not in a position to continue Keynesian policy any longer. It is true that the public debt increased over time, but there is no indication that fiscal policy was conducive to the increase in the ratio of public debt to GDP (column 3 of Table 1). Kendall's coefficient of rank correlation between the fiscal stimulus as a proportion of GDP (column 4) and the rate of increase in public debt ratio to GDP is 0.214 and not significant at even the 10 per cent level of confidence. This indicates a lack of strong evidence in support of claims that the use of fiscal policy in the $1990 \mathrm{~s}$ increased the burden of debt.

\section{Table 1: Public Debt - Its Ratio to GDP, Fiscal Stimulus and the Growth Rate}

(1)

Public debt ${ }^{2}$
(2)

$$
\begin{array}{cc}
\text { Ratio of public } & \text { Growth rate } \\
\text { debt to GDP } & \text { of the ratio }
\end{array}
$$

$\begin{array}{cccccc} & \text { ¥ trillion } & \% & \% & \% & \% \\ 1990 & 288.8 & 65.8 & -11.8 & 0.51 & 5.54 \\ 1991 & 298.2 & 64.4 & -2.1 & 0.52 & 2.95 \\ 1992 & 319.4 & 67.7 & 5.1 & 1.35 & 0.38 \\ 1993 & 344.9 & 72.4 & 9.9 & 1.40 & 0.48 \\ 1994 & 379.8 & 79.3 & 9.5 & 0.66 & 0.64 \\ 1995 & 417.7 & 85.4 & 7.7 & 1.67 & 2.80 \\ 1996 & 454.7 & 90.4 & 5.9 & -0.16 & 3.17 \\ 1997 & 479.4^{\mathrm{b}} & 98.4 & 8.8 & -1.28 & -0.41\end{array}$

Sources: The first table in the Appendix, Japan, Economic Planning Agency (1998:327) and Toyo Keizai Shinposha (1999: Statistical pages 2 and 3, February).

Notes:

a. Total of the outstanding government short-term and long-term bonds and securities, and government borrowings.

b. Extrapolated by outstanding balance of new medium and long-term government debt. 
The relationship between the growth rate and the increase in the public debt ratio is what counts. Kendall's coefficient of rank correlation between the growth rate (column 5) and the rate of increase in the debt ratio (column 3) is minus 0.50 and significant almost at the 5 per cent level of confidence. Thus, high growth rates in 1990 and 1991 were needed to increase revenue rapidly enough to reduce the ratio of public debt to GDP in spite of the use of moderately positive Keynesian fiscal policy. Also, relatively high growth rates in 1995 and 1996 induced a reduction in the rate of increase in the debt ratio, but the growth rates were not really high enough in those years to cause an absolute decline in the debt ratio. Similarly, a negative growth caused by negative fiscal policy in 1997 induced a rapid rise in the rate of increase in the debt ratio.

It may be fair enough to state that a very rapid growth can cause a reduction in the debt ratio, particularly when the growth is accompanied by an increase in private capital formation induced by the narrowing of the negative gap of the operating ratio from the full-utilisation level. Further, a narrowing of the negative gap in the operating ratio can occur only as a result of continuing high growth generated by the adoption of an aggressive fiscal policy.

It should be clear that Keynesian policy was not responsible for the intolerable debt burden. Had Keynesian policy been vigorously applied to achieve sufficiently high economic growth, debt would have been reduced. Hence, the government's adoption of a more audacious fiscal policy would have been appropriate, not only to stimulate growth, but also to reduce the debt burden.

\section{Conclusion}

In this paper it has been argued that fiscal policy supported the growth of the Japanese economy in the 1990 s, but that the stimulus was insufficiently strong to realise the full utilisation of capital and labour. This is an important observation on the Japanese economy over this period, revealing the inadequacy of public policy. The government is held responsible for inadequate employment, bad performance of business firms and the associated tragedies and unhappiness.

Perhaps more interesting to theorists is the rejection of Barro and Lucas's theory of the irrelevance of fiscal policy to economic growth. Barro and Lucas may protest that - just like econometric models of a generation ago - this paper lacks microeconomic foundation. However, it is the contention in this paper that, once one admits that economics is an empirical science, all economic theories will have to be verified empirically and that the theory of fiscal irrelevance can not be adequately verified by studying the Japanese economy in the 1990s. In contrast, the Keynesian theory underlying this paper can be verified.

It is surprising that the irrelevance theory has been tacitly or overtly accepted by almost a generation of economists without being empirically tested, except for the American economy in the 1970s. In my view, unfortunately it has now been adopted by many intermediate macroeconomic textbooks and even some introductory ones. The author hopes that the irrelevance of fiscal policy has been 
rejected convincingly for Japan in the 1990s and that it will be similarly rejected by empirical tests for other countries, inviting a resurgence of Keynesian economics in the world. 
Appendix: The Effect of Fiscal Policy on the Growth Rate of Real GDP A Multiplier Analysis of the Japanese Economy, 1990-1997

\begin{tabular}{|c|c|c|c|c|c|c|c|c|}
\hline $\begin{array}{c}\text { (1) } \\
\text { Change in } \\
\text { private } \\
\text { autonomous } \\
\text { expenditure }\end{array}$ & $\begin{array}{l}\text { (2) } \\
\text { Contrib- } \\
\text { ution of } \\
\text { (1) to } \\
\text { GDP } \\
\text { growth }\end{array}$ & $\begin{array}{c}\text { (3) } \\
\text { Difference } \\
\text { between actual } \\
\text { growth rate } \\
\text { and contribut- } \\
\text { ion of private } \\
\text { growth } \\
\text { (8)-(2) }\end{array}$ & $\begin{array}{c}(4) \\
\text { Change in } \\
\text { public } \\
\text { expenditure }\end{array}$ & $\begin{array}{l}\text { (5) } \\
\text { Tax } \\
\text { b } \\
\text { cut }\end{array}$ & $\begin{array}{l}\text { (6) } \\
\text { Contrib- } \\
\text { ution of } \\
\text { fiscal } \\
\text { policy } \\
\text { to GDP } \\
\text { growth }\end{array}$ & $\begin{array}{c}(7) \\
\text { Total } \\
\text { contrib- } \\
\text { ution }\end{array}$ & $\begin{array}{c}(8) \\
\text { Actual } \\
\text { growth } \\
\text { rate } \\
(2)+(6)\end{array}$ & $\begin{array}{l}(9) \\
\text { Error } \\
(8)-(7)\end{array}$ \\
\hline$¥$ tril & $\%$ & $\%$ & $¥$ tril & $¥$ tril & $\%$ & $\%$ & $\%$ & $\%$ \\
\hline 17.07 & 4.76 & 0.78 & 2.22 & & 0.96 & 5.72 & 5.54 & -0.18 \\
\hline 6.05 & 1.47 & 1.48 & 2.29 & & 1.19 & 2.66 & 2.95 & 0.29 \\
\hline-10.87 & -2.86 & 3.24 & 6.07 & & 2.44 & -0.42 & 0.38 & 0.80 \\
\hline-13.77 & -3.06 & 3.54 & 6.34 & & 2.18 & -0.88 & 0.48 & 1.36 \\
\hline-1.26 & -0.28 & 0.92 & 1.17 & 1.83 & 0.77 & 0.49 & 0.64 & 0.15 \\
\hline 0.29 & 0.06 & 2.74 & 4.17 & 3.67 & 1.93 & 1.99 & 2.80 & 0.81 \\
\hline 11.17 & 3.34 & -0.17 & -0.77 & & -0.23 & 3.11 & 3.17 & 0.06 \\
\hline 0.88 & 0.19 & -0.60 & 1.03 & -7.47 & -1.24 & -1.05 & -0.41 & 0.64 \\
\hline
\end{tabular}

Sources: Japan, Economic Planning Agency (1998:411) and Toyo Keizai Shinposha (1999: Statistical pages 2-3, February).

Notes:

a. Multipliers. The following multipliers were used. Those for 1993-94 and 1997- are from the Japan Research Institute. Those for 1990-92 and 1995-96 were extrapolated or interpolated by the author.

$\begin{array}{lcccc} & 1990-92 & 1993-94 & 1995-96 & 1997- \\ \text { For autonomous expenditure } & 1.80 & 1.56 & 1.40 & 1.21 \\ \text { For permanent tax cut } & & 1.43 & 1.00 & 0.70 \\ \text { For transient tax cut } & & 1.00 & 0.70 & 0.40\end{array}$

b. Tax cuts. For 1994 one third of the tax cut of $¥ 5.5$ trillion was allocated for that fiscal year and a multiplier of 1.0 for the transitory tax cut. Two thirds of the tax cut of 1994 was allocated for 1995 and a multiplier of 0.7 for the transitory tax cut was applied upon $2.0 / 5.5$ of the total amount ( $¥ 3.67$ trillion). For the remainder which was a permanent tax cut a multiplier of 1.00 was used. The permanent tax increase (a rise in the consumption tax rate and an increase in the social security tax) of $¥ 5.0$ trillion was assigned a multiplier of 0.70 . The same multiplier was applied to the increase of medical cost of $¥ 0.8$ trillion although only $7 / 12$ of the total amount was accounted for because the tax was increased in September. Finally, a multiplier of 0.40 was applied to the abolition of the $¥ 2.0$ trillion transitory tax cut. 


\section{References}

Barro, R. (1974), 'Are Government Bonds Net Wealth?', Journal of Political Economy 82(6): 1095117.

Japan, Economic Planning Agency (1998), Annual Report on National Accounts, 1998, Ministry of Finance Printing Bureau, Tokyo.

Lucas, R. (1975), 'An Equilibrium Model of the Business Cycle', Journal of Political Economy 83(6):1113-44.

Lucas, R. (1976), 'Econometric Policy Evaluation: A Critique', Journal of Monetary Economics Supplement ('The Phillips Curve and Labor Markets'):19-40.

Niwa, Haruki (1993), Keinzu wa Ikiteiru (Keynes is Alive), Bijinesu-sha, Tokyo.

Organisation for Economic Development and Cooperation (OECD) (1998), OECD Economic Surveys: Japan 1997-98, Paris.

Toyo Keizai Shinposha (1999), Toyo Keizai Tokei Geppo, Tokyo, February and April.

Yano, Makoto (1991),, 'Temporary Transfer in a Simple Dynamic General Equilibrium Model', Journal of Economic Theory 54:372-88.

Yano, Makoto (1998), 'Ippan Kinko Model niokeru Zaiseiseisaku no Ichijisei to Kokyusei ni tsuite' ('On the Transitivity and Permanence of Fiscal Policy in the General Equilibrium Model'), pp. 77110 in Mikio Otsuki et al. (eds), Gendai Keizaigaku no Choryu, Toyo-keizai Shinposha, Tokyo.

Yasuba, Yasukichi (1993a), 'Shohi Ochikomi Fukyo Shinkokuni - Zaisei Shutsudo ga Kyumu' ('The Decline of Consumption with Recession Deepening - Fiscal Stimulus Needed'), Nihon Keizai Shinbun, January 20.

Yasuba, Yasukichi (1993b), 'Jumpstart Japan's Economy with a Big Fiscal Stimulus', The Japan Times, March 1.

Yasuba, Yasukichi (1993c), 'Zaiseiseisaku no Tenkan - Akujunkan o Dotatsu' ('Change in Fiscal Policy - How to Cut the Vicious Cycle'), Journal of the Japan Center for Economic Research 68:18-23.

Yasuba, Yasukichi (1993d), 'Daikibo Genzei de Yen-daka Fukyo o Dasshutsu Seyo' ('Avoid Yendaka Recession by a Big Tax Cut'), Shukan Daiyamondo, July 3, 54-7.

Yasuba, Yasukichi (1993e), 'Keiki, Keijo Kuroji Taisaku ni Ohaba Shotoku-zei o' ('A Large Income Tax Cut to Solve the Problem of Recession and Current Account Surplus'), Ekonomisuto, September 28, 30-3.

Yasuba, Yasukichi (1994a), 'Fukyo, Nichibei-Kankei to Zaiseiseisaku' ('Recession, JapaneseAmerican Relations and Fiscal Policy'), Nihon Keizai Kenkyu 27(March):1-16.

Yasuba, Yasukichi (1994b), 'Keiki Taisaku ni Shotokuzei Genzei' ('Income Tax Cut for Solving the Problem of Recession'), Nihon Keizai Shinbun, January 21.

Yasuba, Yasukichi (1994c), 'Fiscal Policy and the Burden of the Debt in Japan Since 1982 Indicating MOF's Crime Against Humanity', unpublished. 
Yasuba, Yasukichi (1995), 'Namanurui Seifu no Shinsai Taisaku' ('Unsatisfactory Effort of the Government to Cope with the Earthquake'), Nihon Keizai Shinbun, April 8.

Yasuba, Yasukichi (1996), 'Zaisei Saiken wa Awatezuni' ('Do Not Rush Through the Reconstruction of Public Finance'), The Papers of the Kansai Centre for Economic Research 293(September).

Yasuba, Yasukichi (1999), '2000 nendo 4\% Seicho o' ('Towards a 4\% Growth in Fiscal 2000'), Nihon Keizai Shinbun, February 8.

The author is indebted to the Japan Research Institute for permission to use their multipliers and to Akira Kosaka, Tsuyoshi Yano, Hirosuke Taniguchi and particularly to an anonymous referee for useful comments. Views expressed and errors are strictly attributable to the author. 